\title{
Preparation of future teachers for tourism and local history activities
}

\author{
T.A. Maslova ${ }^{1 *}$, E.A. Akimova ${ }^{2}$, and V.A. Romanov ${ }^{3}$ \\ ${ }^{1}$ V.I. Kaluga State University named after K.E. Tsiolkovsky, Kaluga, Russia \\ ${ }^{2}$ V.I. Kaluga State University named after K.E. Tsiolkovsky, Kaluga, Russia \\ ${ }^{3}$ V.I. Tula State Pedagogical University named after L.N. Tolstoy, Tula, Russia
}

\begin{abstract}
The article deals with the process of preparing students for tourism and local history activities. The need to develop students ' skills in tourism and local history activities is justified by the need to develop components of universal competence specified in the Federal State Educational Standard of Higher Education (FSES HE). The pedagogical conditions necessary for preparing future teachers for tourism and local history activities in higher education are determined. The skills that students should master in the process of preparing for the implementation of tourist and local history activities are highlighted.
\end{abstract}

\section{A problem statement}

The current situation in higher education requires new, modern approaches to the educational training of teachers and their activities. These processes form the prerequisites for creating individually directed educational strategies, for adapting the content of educational programs and manuals to the real needs and capabilities of students, and for moving to the flexible nature of the pedagogical process.

Higher school pedagogy today focuses on the development of means in order to intensify the professional development of the individual. The educational result of becoming a specialist is represented by readiness for professional activity in the logic of the competence approach. In pedagogy, readiness for professional activity is considered as a system of components, personal qualities that ensure the performance of professional functions for a future specialist. This issue is reflected in the works of V.A. Slastenin [1], his scientific school, the works of O.V. Voronova, E.P. Grishina, N.M. Izoria [2], S.V. Kalinina and other young scientists.

The Russian state and society have set a goal for the pedagogical community - to create and implement optimal conditions for the education and development of modern youth.

Article 2, paragraph 1 of the Federal law of the Russian Federation" On Education "defines the concept of education:" 1 . Education - a single purposeful process of education and training, which is a socially significant good and is carried out in the interests of a person, family, society, state, as well as a set of acquired knowledge, skills, values,

\footnotetext{
* Corresponding author: ipcs-profped@yandex.ru
} 
experience and competence of a certain volume and complexity for the purpose of intellectual, spiritual, moral, creative, physical and (or) professional development of a person, for satisfaction of his educational needs and interests" [3].

In the Federal state educational standard of higher education (bachelor's program), the requirements for the results of mastering the bachelor's program specify the following competencies: UC-6. Able to manage their time, build and implement a self-development trajectory based on the principles of education throughout life. UC-7. Able to maintain a proper level of physical fitness to ensure a full-fledged social and professional activity. UC8. Able to create and maintain safe living conditions, including in the event of emergencies [4]. Tourist and local history activities provide such an opportunity.

\subsection{The objective of the work}

Scientific development of issues of tourism and local lore activity is based on the concept of continuity of tourism and local history (A.A. Ostapets-Sveshnikov, I.L. Ivanov, A.D. Soldatenkov, Yu.S. Konstantinov, etc.) [5]. Pedagogical aspects of local history are studied by a number of leading experts in this field (S.O. Schmidt, A.E. Seinensky, V.E. Tumanov, N.I. Reshetnikov [6-7], I. N. beskorovayny, etc.).

The educational role of this activity is revealed in the works of Ya.A. Komensky, I.G. Pestalozzi, V.N. Tatishchev, M.V. Lomonosov, S.M. Golitsyn, Yu.S. Konstantinov, V.M. Kulikov, A.A. Ostapts-Sveshnikov and others. In the Soviet period, the role of children and youth tourism as a means of Communist education of the individual is revealed in the works of I.M. Grev, N.K. Krupskaya, A.E. Fersman, D.A. Shadrikov, S.T. Shatsky, and others. I.V. Zorin analyzed the problems of forming the content of professional tourism education from the position of a systematic approach. He developed the theoretical basis for designing the content of professional tourism education, and presented a method for forming a didactic complex for training tourism specialists [8].

Among the works dedicated to tourist and local history activity of students at the present stage important are the studies of I.A. Drugova, Y.S. Konstantinova [9], A.G. Maslova, G.S. Usyskina et al. Some aspects are revealed in dissertation research, in which tourist and local history activities are presented as a means of professional orientation of students (D.V. Smirnov, etc.); the form of organization of the educational process in school (S.M. Gubanenkov, etc.), education of environmental culture (G.V. bukovskaya [10], V.P. Fomina, etc.), training of personnel for tourist and local history activities (Z. I. Gordeeva) [11], the importance of tourism in the spiritual and Patriotic education of secondary school students (M.A. Gorbova and D.S. Senyuk). The educational value of tourism and local history activities is considered by Yu.T. Borodkina, I.N. Pilat, P.I. Istomin [12-13], M.N. Yamnitsky, V.G. Tsygankov. In their works, the model of formation of young people readiness for responsible interaction by means of sports tourism is tested. Criteria for identifying readiness for conscious, responsible interaction are given.

The Fundamentals of the state youth policy of the Russian Federation for the period up to 25 years reflect proposals for youth involvement: "in the active work of search, archaeological, military-historical, local history, student groups and youth associations" [14].

At the present stage, there are a number of contradictions between:

- the high need of society for a person who is ready to consciously serve the Motherland and the insufficient attention of the Institute of education to the problems of Patriotic education during the active growing up of the younger generation;

- the need for scientific and methodological support for Patriotic education of higher education institutions and insufficient knowledge of the specifics of Patriotic education organization in its, institutions; 
- students ' need for social self-determination and low level of parity of social and personal values.

The development of youth tourism and local history is the most important social order of modern society. The role of the teacher in the formation of a socially active modern personality through tourism and local history activities should not be underestimated. Modern pedagogical science and practice have proved that the training of teachers in the tourist and local history movement is a highly effective means of teaching and educating the younger generation. Training teachers of tourism and local history activities for higher education is not only a personnel issue, but a whole system, a way of life that gives knowledge, skills, and ideology in the education and upbringing of the future generation. It is very important for preserving the identity of the native land, the inadmissibility of falsifying history, and preserving the common history of our homeland.

Among the factors hindering the development of tourism and local history activities in the regions of the Russian Federation, there is a shortage of qualified personnel. Since tourism and local history are not included in the database of General education subjects, such as mathematics or history, etc., they are mostly subjecting of additional education. However, the requirements for tourism and local history activities teachers are generally accepted, and they include all levels of competence and readiness for professional activity.

\section{Materials and the results of the research}

By tourism and local history activities, we will understand tourism and local history activities organized by the public, educational institutions, in order to ensure the pedagogically appropriate use of educational and leisure time, which is an optimized means of harmonizing the training, education and development of young people in the process of tourism and local history.

The purpose of our research is to identify the pedagogical conditions necessary for preparing future teachers for tourism and local history activities in higher education.

Tasks:

1. Consider the current trends in tourism and local history.

2. Consider the psychological and pedagogical foundations of tourism and local history activities.

3. Identify the features of tourism and local history activities formation in higher education.

4. Develop a set of classes on formation, for higher education.

We have determined the pedagogical conditions necessary for preparing future teachers for tourism and local history activities in higher education:

- implementation of the directed formation of professionally significant qualities in tourist and local history activities, through the inclusion of mechanisms of emotional and volitional regulation;

- inclusion of students in reflexive evaluation activities and co-reflection in situations of professional and moral choice and awareness of professional duty;

- creation of a multi-faceted emotionally rich space for interaction between subjects of the educational process, which contributes to the development of skills in tourism and local history;

- inclusion of students in tourist and local history activities: expeditions, exhibitions, hikes, excursions, gatherings, etc., contributing to the formation of spiritual and moral values;

- using tourism and local history activities as a form of additional education for students in the form of tour clubs, youth organizations, museums, educational institutions, etc. 
Components of a student's readiness to organize tourism and local history activities: cognitive, practical, communicative, value, reflexive, motivational, personal (Table 1).

Table 1. Indicators of students ' readiness for tourist and local history activities

\begin{tabular}{|c|c|c|c|}
\hline components & readiness indicators & measurement tools & points \\
\hline Cognitive & $\begin{array}{l}\text { Knowledge of the legal framework of the } \\
\text { tourist and local history activities. Know } \\
\text { Federal and regional Programs, } \\
\text { Instructions, classifications, regulations, } \\
\text { and Laws that regulate tourist and local } \\
\text { history activities in the region. Russia and } \\
\text { abroad. Have an idea of the structure of } \\
\text { interaction between organizations that } \\
\text { implement tourist and local history } \\
\text { activities. Know The Training Programs. } \\
\text { Knowledge of geographical tourist and } \\
\text { local history centers of your region and } \\
\text { regions of Russia. }\end{array}$ & $\begin{array}{l}\text { Survey. } \\
\text { Analysis of students ' } \\
\text { activities. }\end{array}$ & \\
\hline Practical & $\begin{array}{l}\text { Ability to organize various forms of } \\
\text { tourist and local history activities (hikes, } \\
\text { expeditions, excursions, gatherings, } \\
\text { competitions). Ability to conduct } \\
\text { practical exercises (setting up a tent, } \\
\text { organizing a bivouac, lighting a fire, etc.) } \\
\text { Ability to take responsibility. Ability to } \\
\text { build productive relationships with fellow } \\
\text { students, be an organizer and organize for } \\
\text { the sake of achieving a common goal. } \\
\text { Ability to be in demand in the team, to } \\
\text { perform tasks set in the classroom. } \\
\text { Ability to be disciplined and resolve } \\
\text { conflicts. Getting experience of } \\
\text { independent activity, in the process of } \\
\text { working out turnarounds on the ground. }\end{array}$ & $\begin{array}{l}\text { Pedagogical } \\
\text { supervision. } \\
\text { Analysis of students ' } \\
\text { activities. }\end{array}$ & \\
\hline Communicative & $\begin{array}{l}\text { Ability to communicate effectively and to } \\
\text { organize the educational process, } \\
\text { practical activities in the tourist and local } \\
\text { history activities. Involvement of diverse } \\
\text { specialists in the preparation of events in } \\
\text { the shopping center. Initial fundraising } \\
\text { skills (raising funds for organizing events } \\
\text { in the tourist and local history activities.) } \\
\text { Ability to interact with classmates in the } \\
\text { process of organizing tourist and local } \\
\text { history activities. classes. }\end{array}$ & $\begin{array}{l}\text { Pedagogical } \\
\text { supervision. } \\
\text { Conversation. } \\
\text { Analysis of students ' } \\
\text { activities }\end{array}$ & \\
\hline Value & $\begin{array}{l}\text { Value attitude to the tourist and local } \\
\text { history activities, formation of a value } \\
\text { attitude to social reality - a tourist trip, } \\
\text { local history research, tourist club. }\end{array}$ & $\begin{array}{l}\text { Pedagogical } \\
\text { supervision. } \\
\text { Conversation. } \\
\text { Analysis of students ' } \\
\text { activities. }\end{array}$ & \\
\hline Reflexive & $\begin{array}{l}\text { Adequate general and professional } \\
\text { assessment and self-assessment. } \\
\text { Objective assessment of the level of self- } \\
\text { development as a result of tourist and } \\
\text { local history activities classes. Ability to } \\
\text { process and interpret basic knowledge of }\end{array}$ & $\begin{array}{l}\text { Pedagogical } \\
\text { observation. } \\
\text { Conversation. } \\
\text { Analysis of students ' } \\
\text { activities. }\end{array}$ & \\
\hline
\end{tabular}




\begin{tabular}{|c|c|c|c|}
\hline components & readiness indicators & measurement tools & points \\
\hline & $\begin{array}{l}\text { tourist and local history activities and } \\
\text { apply it in the organization and } \\
\text { implementation of tourist and local } \\
\text { history activities (hikes, clubs, } \\
\text { conferences, clubs, excursions, etc.) } \\
\text { Ability to analyze scientific and technical, } \\
\text { specialized information in the } \\
\text { organization of events, classes (study of } \\
\text { special literature, modern equipment, } \\
\text { technical devices, etc.) and apply them in } \\
\text { their activities. Empathy, self- } \\
\text { organization, social reflection. }\end{array}$ & & \\
\hline Motivational & $\begin{array}{l}\text { Desire to acquire knowledge on tourist } \\
\text { and local history activities, the possibility } \\
\text { of their use in professional activities. } \\
\text { Desire to work in the field of tourism and } \\
\text { local lore. Desire to become a high-class } \\
\text { specialist. Desire to get an interesting job. } \\
\text { Desire to work with people. }\end{array}$ & $\begin{array}{l}\text { Pedagogical } \\
\text { supervision. } \\
\text { Conversation. } \\
\text { Analysis of students ' } \\
\text { activities. }\end{array}$ & \\
\hline Personal & $\begin{array}{l}\text { Ability to independently find and use } \\
\text { sources of information on tourism and } \\
\text { local history. Ability to organize work, } \\
\text { take management decisions in the process } \\
\text { of tourist and local history activities (in } \\
\text { the mode of emergencies, unforeseen } \\
\text { circumstances, etc.), qualities: } \\
\text { independence, } \\
\text { organization, tolerance. }\end{array}$ & $\begin{array}{l}\text { Pedagogical } \\
\text { supervision. } \\
\text { Conversation. } \\
\text { Analysis of students ' } \\
\text { activities. }\end{array}$ & \\
\hline
\end{tabular}

The result of professional training of future teachers will be the " readiness assessment " of students to organize tourist and local history activities. The evaluation took into account the indicators of the criteria for the readiness of future teachers to organize tourist and local history activities in educational institutions (Table 2).

High level - from 4 to 5 points.

Average level - from 3 to 4 points

Low level-less than 3 points

Up to $50 \%$ - three points

From $50 \%$ to $75 \%$ - four points

From $75 \%$ to $100 \%$ - five points

Table 2. The level of students ' performance in tourist and local history activities classes

\begin{tabular}{|l|l|l|}
\hline \multirow{2}{*}{ Names of the criterion } & \multicolumn{2}{|c|}{ Level of performance } \\
\cline { 2 - 3 } & The original \% & \multicolumn{1}{c|}{ Total in points } \\
\hline Cognitive & 60 & 4 \\
\hline Practical & 79 & 5 \\
\hline Communication & 78 & 5 \\
\hline Value & 70 & 4 \\
\hline Reflexive & 80 & 5 \\
\hline Motivational & 95 & 5 \\
\hline Personal & 90 & 5 \\
\hline
\end{tabular}

After analyzing the indicators of students ' readiness for tourism and local history activities, we can identify the following levels of readiness: 
1. System-modulating (high) - ability to form a system of knowledge, skills and abilities on the tourism and local history activities as a whole.

2. Local-modulating (average) - knowledge and skills transfer skills for individual sections and topics of the tourism and local history activities.

3. Reproductive, adaptive (low) - is the ability to tell what he knows about the tourism and local history activities, ability to adapt your knowledge to the characteristics of the audience.

The results of the students ' assessment of their own training allowed them to evaluate the levels according to the 5-point system.

At the first, high level, we can say about the pedagogical giftedness of students, which is manifested in the ability to subordinate their interests to the achievement of a goal: in our case, autonomous survival in the wild. At a high level special abilities of students are distinguished: stress resistance to unforeseen situations, the ability to organize the process of self-survival in extreme conditions, and the ability to organize a group and offer their own solutions to the situation. They used mostly professional terminology: "I can organize a hike, I can organize and hold a conference, I can conduct practical classes on organizing a bivouac, lighting a fire, setting up a tent, I independently develop training programs and conduct training, etc»).

Second-and middle-level students mainly used general concepts: "I can teach the technique of setting up a tent, the technique of lighting a fire, the technique of organizing a bivouac; ...I mastered the methods of organizing excursions, methods of collecting local history material". Middle-level students showed practical, communicative reflexive abilities to reproduce the worked-out process of self-survival in extreme conditions and to organize a group. However, they offered standard solutions to the situation. Middle-level students had a general characteristic of tourist and local history activities.

Students of the third low level do not have conscious strategies of tourist and local history activities, they carried it out mainly due to their knowledge and intellectual qualities, under the guidance of a teacher, receiving clear instructions in the process of work. They avoided a direct answer and did not take the initiative. Low-level students had the terminology: "I can hold classes, I can set up a tent, light a fire, organize a bivouac».

The assessment of independent activity of students is adequate, allowing to determine the level of their own competence and readiness to apply it in teaching activities.

Only a thinking, competent, adaptive specialist who is able to organize the conditions for achieving results in the labor code will be competitive and in demand in the labor market. He will be able to provide knowledge and skills that are simply necessary in modern life. To date, we see that we are not protected from emergencies, when threats to the life of the population appear suddenly and unexpectedly, knowledge of tourist and local history activities becomes especially relevant. And higher education should not be left out of it.

Knowing the methods of tourist and local history activities, self-survival techniques we can successfully organize our safety, our survival not only in the wild, but also in megacities and in general at any point of residence and in any situation.

Before and after the practical training, we conducted a written survey by means of a questionnaire among the students of Kaluga State University (KSU) named after K.E. Tsiolkovsky.

Questionnaire

1. What do you know about tourism and local history?

2. Give your definition: Tourism is -

3. What do you understand by local history?

Continue with the phrase local history is - 
4. Do you think we need teacher training for the tourist and local history activities. Underline the right answer.

Yes No

5. What modern types of tents do you know?

6. What is the main factor of autonomous survival in the natural environment in the event of an emergency?

7. What tourist equipment would you take with you in case of an emergency?

8. What do you know about the Department of tourism at KSU?

9. What public associations dealing with tourist and local history activities are there in KSU?

10. Where would you use and apply your knowledge of tourist and local history activities as a teacher?

11. Would you expand your opportunities as a teacher when applying practical skills in tourist and local history activities in teaching activities and why?

12. What are the main rivers of the Kaluga region?

13. Name the Reserves of the Kaluga region.

14. What is ecoduct, and where were built the first Russian ecoducts?

15. Name the National parks of the Kaluga region.

16. Are you interested in knowledge about the Kaluga region? Underline your answer.

Yes No

17. What new things did you learn in the tourist and local history activities class?

18. What important event is our country celebrating in may 2020 ?

19. What do you know about the Museum at KSU named after K. E. Tsiolkovsky?

20. What forms of work on tourist and local history activities would you choose as a teacher?

21. Your Small Homeland. Tell your little story about it.

22. What do you personally mean by the concept of Patriotism?

23. Do to date in higher education, tourist and local lore activity, and why?

24. Do you think it is necessary to introduce such a form of additional education in KSU as a tourist circle or tour club? Or write your proposal.

25. What form would you choose: a hike, an excursion, an expedition (local history, tourism, ethnography)?

26 . What safety rules do you know when hiking in the woods?

27. In what form of tourist and local history activities would your independent activity and your personality be more clearly manifested?

28. In what kind of tourist and local history activities would you get a versatile experience?

29. Would you like to use the development of practical classes on tourist and local history activities as future teachers and why?

30. Do you think it is necessary to introduce tourist and local history activities in the educational process of higher education as a subject and why?

31. What are your suggestions for improving the teaching of tourist and local history activities.

The development of a set of practical exercises on tourist and local history activities was carried out in practice.

\section{Lesson №1}

Practical lesson "Technique of autonomous survival in the wild" wild.

The purpose of the lesson: to develop students ' primary skills and survival skills in the

Tasks: 
To introduce students to the basics of survival in the wild and the use of improvised means of protection from the adverse environmental factors.

To give the basic skills of survival techniques in the forest and the construction of temporary shelters.

Practice skills in building temporary shelters.

Practice skills in using improvised means of protection against the impact of adverse environmental factors.

\section{Lesson №2}

The Theme: "Safety instructions for tourist and local history events. Type of trips"

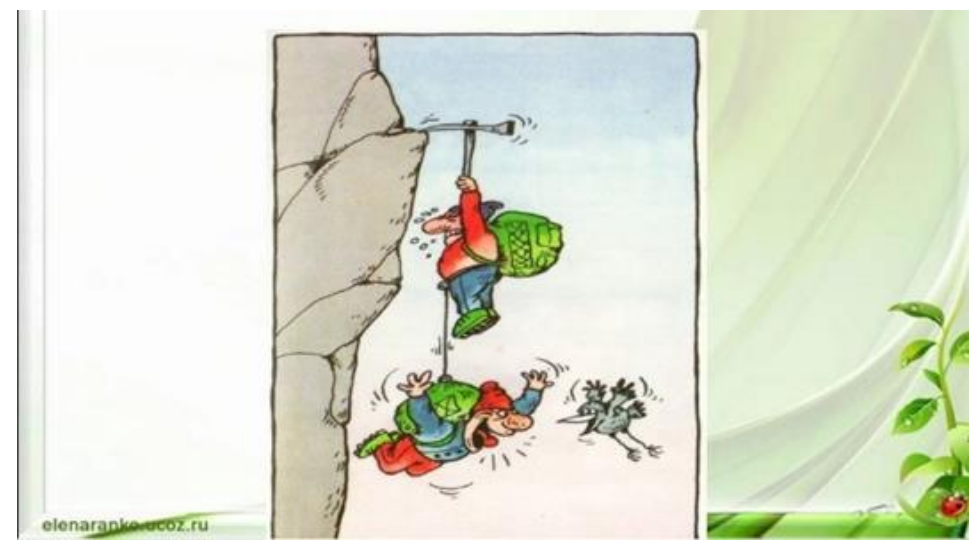

Fig. 1. security measures.

Practical lesson: "Types of instructions", "Safety Instructions for tourists on a hike".

The purpose of the lesson: to give primary knowledge about the types of instructions and learn the types of safety Instructions in the campaign.

Tasks:

To introduce students to the types of training sessions.

To learn different types of safety Instructions on a hike.

Training methods: visual and demonstration.

Venue: auditorium of KSU.

Class type combined

Form of classes: group, classroom.

Equipment: multimedia equipment, presentation.

\section{Lesson №3}

Seminar-game for students in "Hooray, we are going on a hike", as part of the tourist and local history activities

Purpose of the workshop:

Get organizational and practical skills on the topic: "Organization and conduct of a hiking trip" "Extreme situation in a hike".

Objectives of the workshop:

To prepare students to solve situational problems using the design method.

To give the concept of "what is an extreme situation" and to form the rules of personal behavior in the team together with students.

To promote awareness of self-organization, students ' understanding of collectivism, when solving the problem of survival in the natural environment.

Correctional: to promote the formation of students ' communication skills. 
Problematic situation: the use of theoretical knowledge and skills "Organization and conduct of hiking" and "Behavior in an extreme situation" in practice.

\section{Lesson №4 Practical lesson "setting up a Tent"}

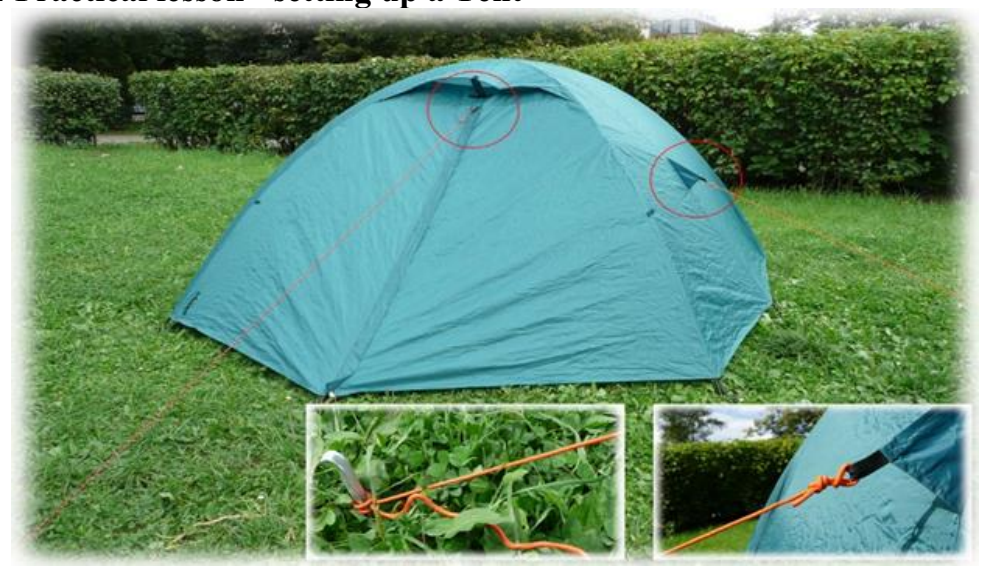

Fig. 2. setting up the tent. tents

The purpose of the lesson: to develop students ' skills to install various types of

Tasks:

To introduce students to the types of tents.

To give primary skills in choosing a place to set up a tent.

Demonstration of the installation of a classic tent.

Formation of students ' skills to install various types of tents by practicing turnovers on the ground.

1. The skills of camping.

2. Demonstration of the installation of a classic tent.

3. Demonstration of the installation of a modern tent hemisphere.

\section{Conclusions}

Regular and extracurricular tourist and local history activities will make it possible to produce not only specialists with professional knowledge, but also to get teachers of a new formation who can combine knowledge, an active life position, educational functions. It forms a new generation, figuratively speaking, combining "both lyricists and physicists", professional knowledge and universal values. Only a thinking, competent, adaptive specialist who is able to organize the conditions for achieving results in the labor code will be competitive and in demand in the labor market, will be able to provide knowledge and skills that are simply necessary in modern life.

We can see that we are not protected from emergencies, when threats to the life of the population appear suddenly and unexpectedly. Knowledge of tourist and local history activities becomes especially relevant nowadays, and higher education should not be left out of this. Knowing the methods and methods of tourist and local history activities, selfsurvival techniques, we can successfully apply them. We can organize our safety, our survival not only in the wild, but also in megacities and in general at any point of residence and in any situation.

Systematic introduction of the subject "tourist and local history activities" to the training of higher school teachers will make it possible to form a special system of interaction and mutual support among young people. On the one hand, this will provide the 
knowledge necessary for survival in the modern world, and on the other hand, it will form a society in which people will not be strangers to each other, capable of empathy and mutual assistance. Participation in campaigns, expeditions, meetings, excursions and conferences will encourage the development of friendly relations. Now this part of the educational process is almost lost due to attempts to transfer tourist and local history activities to commercial tracks. Its development, the study of the ethnography, culture, and nature of our multi-ethnic state, promotes tolerance, understanding that we are united, that every shade of diversity of cultures and peoples inhabiting our common Homeland is a significant part of universal prosperity and success. In the consolidation of the tourist team, an important role is played by joint activities in the campaign, in the process of which there are relations of interdependence. A.S. Makarenko considered the relationship of interdependence to be the most important lever of collective cohesion. "The members of the collective, "he said," are not free"," do not move in empty space", they are bound by their obligations or relations with the collective, their duty to the collective... the question of the relationship of a comrade to a comrade is a question of responsible dependence" [15].

All subjects taught in higher education are designed to contain a moral foundation. Students, as future teachers, should be aware of their purpose and distinguish formal education from professionalism through life, excursions, trips to their native land. An important tool in teaching a modern teacher is tourism and local history.

Proficient in this subject, the teacher will not only interest students, but also form their professionalism, active citizenship and life position. The introduction of tourism and local history activities in the interdisciplinary courses of higher education institutions will encourage the production of highly qualified professional teachers. The education of an active vital position and patriotism, civil responsibility should be specific examples: teaching tolerance - by studying Ethnography, education of patriotism - on the study of history, moral education and intelligence - the study of cultural heritage, etc. All this gives tourism and local history. During hikes and excursions, students not only gain knowledge of geography, history, and culture, but also improve themselves as individuals. Today, tourism and local history activities are a means of comprehensive development of the individual, a means of connecting higher education with society through the regional component. Students who are engaged in tourism and local history are more adaptable to life conditions, stress-resistant, are not afraid to take responsibility for themselves and will always find a way out of extraordinary situations.

\section{References}

1. V.A. Slastenin, Formation of the personality of a Soviet school Teacher in the process of professional training, 160 (Moscow: Prosveshchenie, 1976)

2. N.M. Izoria, Personal-oriented approach to training specialists of foreign language competence in the field of tourism, Innovative technologies for teaching cultural and leisure activities, 161-168 (Moscow, MGUKI, 2007)

3. Federal Law "On Education", 273 (dated December 29, 2012)

4. Federal State Educational Standard of Higher Education - Bachelor's degree in the field of training 03/44/01 Pedagogical education, 121 (dated 02.22.2018)

5. A.A. Ostapets, Pedagogy and psychology of tourist and local history activities of students: methodical edition, 87 (Moscow, 2001)

6. S.O. Schmidt, Local history and documentary monuments, 100 (Tver, 1992)

7. N.I. Reshetnikov, Local historian as a discoverer and Keeper of memory, Bulletin of children and youth tourism in Russia, 2 (26), 16-19 (1998) 
8. I.V. Zorin, A.I. Zorin, Professional education and career in tourism: textbook, 528 (Moscow, 2005)

9. I.A. Drogov, Yu.S. Konstantinov, Problems and prospects of social and sports tourism: collection of scientific articles and materials of the International scientific and practical conference, 256 (Moscow: Mosgorsyutur, 2012)

10. G.V. Bukovskaya, Formation of ecological culture of Junior schoolchildren by means of local history and tourism activities, 19 (Moscow, 1997)

11. Z.I. Gordeeva, Goals, tasks and prospects of participation of pedagogical universities in training for tourist and local history activities of schoolchildren, Problems of youth tourism, 1, 42-46 (1998)

12. I.N. Pilat, Extracurricular tourist and local history work as a factor of moral education of teenagers, Autoref. dis. candidate of pedagogical Sciences, 19 (Moscow, 1970)

13. P.I. Istomin, Tourist activity of schoolchildren: Questions of theory and methodology, 94 (Moscow, 1987)

14. Fundamentals of the state youth policy of the Russian Federation for the period up to 2025 Order of November 29 (Moscow, 2014)

15. A.S. Makarenko, Essays. Text: in 7 vols. Akad. PED. Sciences of the RSFSR. Institute of theory and history of pedagogy (Moscow, 1957-1958) 